\title{
A systematic review and meta-analyses of nonsucrose sweet solutions for pain relief in neonates
}

\author{
Mariana Bueno $\mathrm{PhD}^{1}$, Janet Yamada $\mathrm{PhD}^{2,3}$, Denise Harrison $\mathrm{PhD}^{4,5,6,7}$, Sobia Khan $\mathrm{BSc}^{3}$, Arne Ohlsson MD MSc ${ }^{8,9}$, \\ Thomasin Adams-Webber MLS ${ }^{3}$, Joseph Beyene $\mathrm{PhD}^{3,9}$, Bonnie Stevens $\mathrm{PhD}^{2,3,8,10}$
}

\begin{abstract}
M Bueno, J Yamada, D Harrison, et al. A systematic review and meta-analyses of nonsucrose sweet solutions for pain relief in neonates. Pain Res Manag 2013;18(3):153-161.
\end{abstract}

BACKGROUND: Sucrose has been demonstrated to provide analgesia for minor painful procedures in infants. However, results of trials investigating other sweet solutions for neonatal pain relief have not yet been synthesized.

OBJECTIVE: To establish the efficacy of nonsucrose sweet-tasting solutions for pain relief during painful procedures in neonates.

METHOD: The present article is a systematic review and meta-analyses of the literature. Standard methods of the Cochrane Neonatal Collaborative Review Group were used. Literature searches were reviewed for randomized controlled trials investigating the use of sweet solutions, except sucrose, for procedural pain management in neonates. Outcomes assessed included validated pain measures and behavioural and physiological indicators.

RESULTS: Thirty-eight studies (3785 neonates) were included, 35 of which investigated glucose. Heel lancing was performed in 21/38 studies and venipuncture in 11/38 studies. A 3.6-point reduction in Premature Infant Pain Profile scores during heel lances was observed in studies comparing $20 \%$ to $30 \%$ glucose with no intervention (two studies, 124 neonates; mean difference -3.6 [95\% CI -4.6 to -2.6$]$; $\left.\mathrm{P}<0.001 ; \mathrm{I}^{2}=54 \%\right)$. A significant reduction in the incidence of cry after venipuncture for infants receiving $25 \%$ to $30 \%$ glucose versus water or no intervention was observed (three studies, 130 infants; risk difference -0.18 [95\% CI -0.31 to $-0.05] ; \mathrm{P}=0.008$, number needed to treat $=6[95 \% \mathrm{CI} 3$ to 20$] ; \mathrm{I}^{2}=63 \%$ ). CONCLUSIONS: The present systematic review and meta-analyses demonstrate that glucose reduces pain scores and crying during single heel lances and venipunctures. Results indicate that 20\% to 30\% glucose solutions have analgesic effects and can be recommended as an alternative to sucrose for procedural pain reduction in healthy term and preterm neonates.

Key Words: Analgesia; Glucose; Infant; Neonate; Pain; Sweet-tasting solution

\section{Une analyse systématique et des méta-analyses de solutions sucrées sans saccharose pour soulager la douleur chez les nouveau-nés}

HISTORIQUE : Il est démontré que le saccharose sert d'analgésie lors d'interventions mineures douloureuses chez les nourrissons. Cependant, il n'existe pas de synthèse des résultats d'essais sur d'autres solutions sucrées pour soulager la douleur.

OBJECTIFS : Établir l'efficacité de solutions au goût sucré sans saccharose pour soulager la douleur pendant des interventions douloureuses chez les nouveau-nés.

MÉTHODOLOGIE : Le présent article se compose d'une analyse systématique et de méta-analyses des publications. Il fait appel aux méthodes standards du Cochrane Neonatal Collaborative Review Group. Les chercheurs ont analysé les recherches dans les publications pour trouver des essais aléatoires et contrôlés sur l'utilisation de solutions sucrées, à part le saccharose, pour gérer la douleur causée par des interventions chez les nouveau-nés. Les issues évaluées incluaient les mesures de douleur validées et les indicateurs comportementaux et physiologiques.

RÉSULTATS : Trente-huit études (3 785 nouveau-nés) étaient incluses, dont 35 portaient sur le glucose. Des incisions au talon ont été exécutées dans 21 des 38 études et une veinopuncture, dans 11 des 38 études. On observait une diminution de 3,6 points aux indices du profil de douleur des nourrissons prématurés pendant l'incision au talon dans les études comparant de $20 \%$ à $30 \%$ de glucose à l'absence d'intervention (deux études, 124 nouveau-nés, différence moyenne de $-3,6$ [95 \% IC -4,6 à -2,6]; $\mathrm{P}<0,001)$. On observait également une réduction significative de l'incidence de pleurs après la veinopuncture chez les nourrissons qui recevaient de $25 \%$ à $30 \%$ de glucose par rapport à de l'eau ou à l'absence d'intervention (trois études, 130 nourrissons; différence de risque de $-0,18$ [95 \% IC -0,31 à -0,05]; $\mathrm{P}=0,008$, nombre nécessaire pour traiter = 6 [95 \% IC 3 à 20]; I2=63\%).

CONCLUSIONS : La présente analyse systématique et les présentes méta-analyses ont démontré que le glucose réduit les indices de douleur et les pleurs pendant de simples incisions au talon et des veinopunctures. Selon les résultats, des solutions de $20 \%$ à $30 \%$ de glucose ont des effets analgésiques et peuvent être recommandées pour remplacer le saccharose en vue de réduire la douleur lors d'interventions chez les nouveau-nés en santé à terme et prématurés.

It is, however, important to establish the effectiveness of alternative interventions for pain relief in neonates, such as sweet solutions other than sucrose. Alternative sweet solutions may be more accessible than sucrose in clinical settings. Randomized controlled trials (RCTs) have been conducted on sweet solutions other than sucrose for several years; however, the results of these trials have not yet been synthesized.

The aim of the present study was to review the efficacy and safety of sweet-tasting solutions other than sucrose during acute procedural pain in neonates. studied sweet solution, and its short-term safety and effectiveness for analgesia during minor procedural pain in neonates have been demonstrated in a systematic review and meta-analysis (9).

\footnotetext{
${ }^{1}$ School of Nursing, Federal University of Minas Gerais, Belo Horizonte, Brazil; ${ }^{2}$ Lawrence S Bloomberg Faculty of Nursing, University of Toronto, ${ }^{3}$ The Hospital for Sick Children, Toronto; ${ }^{4}$ Faculty of Health Sciences, University of Ottawa; ${ }^{5}$ Children's Hospital of Eastern Ontario, Ottawa, Ontario; ${ }^{6}$ Critical Care and Neurosciences, Murdoch Children's Research Institute, Royal Children's Hospital, Victoria; ${ }^{7}$ Melbourne School of Health Sciences, The University of Melbourne, Melbourne, Australia; ${ }^{8}$ Department of Pediatrics, Obstetrics and Gynecology, Faculty of Medicine; ${ }^{9}$ Department of Health Policy, Management and Evaluation, Faculty of Medicine; ${ }^{10}$ University of Toronto Centre for the Study of Pain, University of Toronto, Toronto, Ontario

Correspondence: Dr Mariana Bueno, Avenida Alfredo Balena, 190, 30130-100, Belo Horizonte, Brazil. Telephone 55-31-3409-9859,

fax 55-31-3409-9860, e-mail maribueno@hotmail.com, buenom@enf.ufmg.br
} 


\begin{tabular}{|c|c|}
\hline \multicolumn{2}{|r|}{ Total citations identified ( $\mathrm{n}=1998)$} \\
\hline$\longmapsto$ & Duplicates excluded ( $\mathrm{n}=1097)$ \\
\hline \multicolumn{2}{|r|}{ Unique abstracts identified $(n=901)$} \\
\hline & 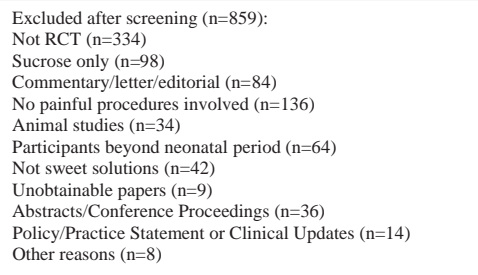 \\
\hline \multicolumn{2}{|c|}{ Full paper retrieved $(n=42)$} \\
\hline$\longmapsto$ & A waiting Classification $(n=4)$ \\
\hline \multicolumn{2}{|r|}{ A rticles included in the systematic review ( $\mathrm{n}=38$ papers, 3,785 infants) } \\
\hline
\end{tabular}

Figure 1) Study selection process for systematic review. RCT Randomized controlled trial

\section{METHODS}

\section{Search strategy}

Electronic searches were conducted in MEDLINE, Embase, and PsycINFO on Ovid, and in the Cumulative Index to Nursing and Allied Health Literature on EBSCO, from the start date of each database to July 31, 2011. Search terms included: pain*, infant*, neonat*, newborn*, lactose, glucose, fructose, glycerine, dextrose, aspartame, polycose, saccharose, saccharide and alternative names for each type of sugar. Additional studies were identified from reference lists, manual searches of key literature, key informants and scientific meeting proceedings. No restrictions on language, year of publication or publication status were imposed.

\section{Study selection}

RCTs studying term and preterm neonates (from birth to one month of age) undergoing any painful procedures and receiving nonsucrose sweet solutions as analgesia were considered for inclusion. Interventions in the control and/or comparison groups included no intervention, oral administration of water, sucrose, breast milk or formula, and breastfeeding. Studies reporting the use of pacifier, positioning, swaddling, cuddling, skin to skin contact and topical anaesthetic agents in combination with or in comparison with sweet solutions were included.

Two independent reviewers $(\mathrm{MB}$ and $\mathrm{DH})$ screened abstracts to identify eligible studies. Full-text articles of potentially relevant abstracts were retrieved and independently assessed for inclusion. Discrepancies were resolved through a consensus process between the reviewers or with a third reviewer (JY) if necessary.

\section{Assessment of bias risk}

Risk of bias of RCTs were assessed using the Cochrane Collaboration criteria (10), which included the following: adequate randomization sequence generation; adequate allocation concealment; blinding of intervention; incomplete outcome data addressed; free of selective outcome reporting; free of other potential sources of bias. Possible responses were low risk, high risk and unclear risk. Two reviewers (MB and SK) independently assessed each study for risk of bias; differences were resolved by discussion. A third reviewer (JY) was consulted if discrepancies remained.

\section{Data extraction}

Data extracted from each study included age, number of infants allocated, comparison groups including type of painful procedure, type of sweet solution(s), concentration and volume of solution(s) administered, study outcomes and adverse events. Where possible, authors were contacted for missing information/data or data clarification. Two reviewers (MB and $\mathrm{SK}$ ) extracted data from the studies using a standardized, pretested form. Differences were resolved by discussion or by a third reviewer (JY) when necessary.

\section{Data synthesis}

The primary outcome of interest was pain scores assessed by a validated unidimensional, multidimensional and/or composite pain measurement tool. Physiological pain indicators (ie, heart rate [HR], HR variability, respiratory rate $[\mathrm{RR}]$, oxygen saturation $\left[\mathrm{O}_{2}\right.$ Sat], skin conductance), behavioural pain indicators (eg, crying features, facial or body actions) and adverse events were reported.

When data were available from at least two studies using the same intervention and outcome measure, a meta-analysis was performed using a fixed-effects model. A mean difference (MD) was reported for continuous variables and typical relative risk for dichotomous data with 95\% CIs. Risk difference (RD) was calculated, and number needed to treat to benefit or harm were calculated if the RD was significant. Between-study heterogeneity was determined using the $\mathrm{I}^{2}$ statistic. RevMan 5.1 software (Cochrane Collaboration, Denmark) was used to analyze the data (11).

\section{Study organization}

Reporting for the present systematic review was conducted in accordance with the recommendations of the Preferred Reporting Items for Systematic Reviews and Meta-Analyses statement (12).

\section{Included studies}

\section{RESULTS}

Of 1998 identified citations, 901 were unique studies. Forty-two studies met the inclusion criteria. On further evaluation of full-text articles, it was unclear whether four studies (13-16) were RCTs. Authors were contacted but did not respond before the completion of the present review; therefore, these studies are currently awaiting classification. Thirty-eight studies (enrolling 3785 infants) were included (Figure 1).

Glucose was investigated in 35 trials, with doses ranging from $0.2 \mathrm{~mL}$ to $2 \mathrm{~mL}$ of $5 \%$ to $50 \%$ solutions. Other solutions studied were artificial sweeteners (17), fructose (18), glycine (17), honey (19) and maltitol (20).

Solutions were administered to the anterior portion of the tongue using a syringe in the majority of the trials. Akcam and Ormeci (21) compared the use of spray and syringe to administer 30\% glucose to infants. Non-nutritive sucking was offered in combination with the sweet solution in five trials (22-26). In four studies, neonates were stimulated to suck the syringe during the administration of the solutions (27-30). Gradin et al (31) described the use of a pacifier or a finger for providing sucking after offering the solution as optional. Finally, Kass and Holman (32), Sajedi et al (33) and Gharehbaghi and Ali (34) did not provide sufficient information regarding the methods used to administer sweet solutions before the procedure.

Control and/or comparison groups received water (with or without sucking), pacifier, swaddling, skin to skin contact, sensorial saturation, facilitated tucking, sucrose solution (with or without sucking), breastfeeding, expressed breast milk, $2.5 \%$ lidocaine $/ 2.5 \%$ prilocaine cream (EMLA; AstraZeneca, United Kingdom), dorsal penile nerve block, acetaminophen, oxycodone or inhaled sevoflurane. No intervention groups were included in eight trials and water groups were included in 19 trials. In six trials, both no intervention and water groups were evaluated (Table 1).

Painful procedures investigated were heel lance (19 studies), venipuncture (10 studies), intramuscular injection (three studies), subcutaneous injection (one study), peripherally inserted central catheter (PICC) placement (one study), eye examination for retinopathy of prematurity (one study) and circumcision (one study). Two studies analyzed pain during different procedures: heel lance and venipuncture (one study), and heel lance and pharyngeal suctioning (one study).

\section{Risk of bias}

Six trials were considered to have a low risk of bias because authors provided sufficient information to make a judgement $(18,21,24,31,35,36)$. 
TABLE 1

Characteristics of included studies

\begin{tabular}{|c|c|}
\hline Author (reference), year; n & Comparison groups \\
\hline \multicolumn{2}{|l|}{ Heel lance } \\
\hline $\begin{array}{l}\text { Ahn et al (43), 2006; } \\
n=60 \text { term infants }\end{array}$ & $\begin{array}{l}50 \% \text { glucose } \\
\text { Water } \\
\text { No intervention }\end{array}$ \\
\hline $\begin{array}{l}\text { Akcam and Ormeci (21), 2004; } \\
\text { n=60 term infants }\end{array}$ & $\begin{array}{l}30 \% \text { glucose } \\
30 \% \text { glucose spray } \\
\text { Water }\end{array}$ \\
\hline $\begin{array}{l}\text { Akcam (18), 2004; } \\
\text { n=34 term infants }\end{array}$ & $\begin{array}{l}30 \% \text { glucose } \\
30 \% \text { fructose } \\
\text { Water }\end{array}$ \\
\hline $\begin{array}{l}\text { Bellieni et al }(25), 2007 ; \\
n=66 \text { term infants }\end{array}$ & $\begin{array}{l}\text { SS by nurses, } 33 \% \\
\text { glucose and pacifier } \\
\text { SS by mothers, } 33 \% \text { glucose } \\
\text { and pacifier } \\
30 \% \text { glucose and pacifier }\end{array}$ \\
\hline $\begin{array}{l}\text { Bellieni et al (30), 2003; } \\
n=17 \text { preterm infants }\end{array}$ & $\begin{array}{l}10 \% \text { glucose and sucking } \\
\text { SS plus } 10 \% \text { glucose and } \\
\text { sucking } \\
\text { No intervention }\end{array}$ \\
\hline $\begin{array}{l}\text { Bellieni et al (29), 2002; } \\
n=120 \text { term infants }\end{array}$ & $\begin{array}{l}\text { 33\% Glucose } \\
\text { 33\% Glucose and sucking } \\
\text { SS, water and sucking } \\
\text { SS, 33\% glucose and sucking } \\
\text { Water and sucking } \\
\text { No intervention }\end{array}$ \\
\hline $\begin{array}{l}\text { Bellieni et al (27), 2001; } \\
n=17 \text { preterm infants }\end{array}$ & $\begin{array}{l}10 \% \text { glucose } \\
10 \% \text { glucose and sucking } \\
\text { SS and glucose } \\
\text { Water and sucking } \\
\text { No intervention }\end{array}$ \\
\hline $\begin{array}{l}\text { Bonetto et al (47), 2008; } \\
n=76 \text { term infants }\end{array}$ & $\begin{array}{l}25 \% \text { glucose } \\
\text { Acetaminophen } \\
2.5 \% \text { lidocaine } 2.5 \% \text { prilocaine } \\
\text { cream } \\
\text { Water }\end{array}$ \\
\hline $\begin{array}{l}\text { Brovedani et al (44), 2007; } \\
n=197 \text { term infants }\end{array}$ & $\begin{array}{l}20 \% \text { glucose } \\
\text { SS } \\
\text { Swaddling } \\
\text { Breastfeeding }\end{array}$ \\
\hline $\begin{array}{l}\text { Bucher et al (17), 2000; } \\
n=80 \text { term infants }\end{array}$ & $\begin{array}{l}\text { Glycine } \\
\text { Artificial sweetener } \\
\text { Expressed breast milk } \\
\text { Water }\end{array}$ \\
\hline $\begin{array}{l}\text { Freire et al }(50), 2008 \\
n=95 \text { preterm infants }\end{array}$ & $\begin{array}{l}25 \% \text { glucose } \\
\text { Skin to skin contact } \\
\text { No intervention }\end{array}$ \\
\hline $\begin{array}{l}\text { Guala et al (28), 2001; } \\
\text { n=65 term infants }\end{array}$ & $\begin{array}{l}5 \% \text { glucose } \\
33 \% \text { glucose } \\
\text { Water } \\
\text { No intervention }\end{array}$ \\
\hline $\begin{array}{l}\text { Guala and Giroleti (37), 1998; } \\
\text { n=140 term infants }\end{array}$ & $\begin{array}{l}5 \% \text { glucose } \\
33 \% \text { glucose } \\
50 \% \text { glucose } \\
33 \% \text { sucrose } \\
50 \% \text { sucrose } \\
\text { Water } \\
\text { No intervention }\end{array}$ \\
\hline
\end{tabular}

Outcome measures and main results

Lower NIPS scores for glucose group ( $\mathrm{P}=0.020, \mathrm{P}=0.021, \mathrm{P}=0.033$ at all time points).

No significant differences in $\mathrm{HR}$, respiration rate, $\mathrm{O}_{2}$ Sat and cry.

Lower DAN scores for both glucose groups compared with water $(P<0.001$ for both).

No significant differences between glucose solution and spray for DAN scores.

Lower DAN scores for glucose and fructose groups ( $P<0.001$ for both compared with water). No significant differences between glucose and fructose for DAN scores.

Lower ABC scores for SS by mothers $(P=0.03)$ and by nurses $(P=0.006)$ compared with glucose and pacifier alone.

Reduced crying time for SS, glucose and sucking group ( $P=0.0004)$ compared with no intervention.

SS, glucose and sucking more effective than glucose and sucking alone at reducing crying time $(P=0.01)$.

Lower DAN scores for glucose and sucking; SS, glucose and sucking ( $P<0.0001$ for both); and

water and sucking $(\mathrm{P}=0.001)$ compared with no intervention.

SS and glucose more effective than glucose and sucking at reducing DAN score $(P=0.004)$.

Lower PIPP scores for glucose alone $(P<0.01)$, sucking $(P<0.01)$, glucose and sucking

$(P<0.001)$, and SS $(P<0.0001)$ compared with no intervention.

SS and glucose more effective than glucose and sucking $(P<0.01)$ at reducing PIPP scores.

No significant differences in PIPP scores between the groups.

Lower NIPS scores for glucose group compared with 2.5\% lidocaine/2.5\% prilocaine cream, acetaminophen and water groups. No $\mathrm{P}$ values provided.

No significant differences in PIPP scores between glucose and breastfeeding groups. Breastfeeding more effective than SS and swaddling ( $P<0.001$ for both) at reducing PIPP scores.

No significant differences in IBCS and NFCS scores among the groups. Lower combined score (IBCS and NFCS) for the sweetener group ( $\mathrm{P}=0.036)$

No significant difference in HR increase among all groups. HR recovered more quickly in the sweetener group compared with other groups $(P=0.04)$.

Reduced crying time $(\mathrm{P}=0.04)$ for sweetener group and longer crying time for glycine group

$(P=0.01)$ compared with other solutions

Quicker recovery $(P=0.01)$ for sweetener group compared with other solutions.

Lower PIPP scores for glucose group compared with no intervention (overall $P=0.0001$ )

Skin to skin contact more effective than glucose at reducing PIPP scores.

Higher HR increase for $5 \%$ glucose group compared with no intervention $(P<0.01) 33 \%$ glucose $(P<0.05)$

No significant differences in HR values among the groups. 
TABLE 1 - CONTINUED

Characteristics of included studies

\begin{tabular}{|c|c|c|}
\hline Author (reference), year; $\mathbf{n}$ & Comparison groups & Outcome measures and main results \\
\hline $\begin{array}{l}\text { Isik et al (38), 2000; } \\
\mathrm{n}=113 \text { term infants }\end{array}$ & $\begin{array}{l}10 \% \text { glucose } \\
30 \% \text { glucose } \\
30 \% \text { sucrose } \\
\text { Water }\end{array}$ & $\begin{array}{l}\text { No significant differences in HR values among the groups. } \\
\text { No significant differences in crying time for } 10 \% \text { and } 30 \% \text { glucose groups compared with water. } \\
\text { Sucrose superior to } 10 \% \text { glucose }(P=0.003) \text { and } 30 \% \text { glucose }(P=0.006) \text { for crying time. }\end{array}$ \\
\hline $\begin{array}{l}\text { Jatana et al (40), 2003; } \\
\mathrm{n}=125 \text { term infants }\end{array}$ & $\begin{array}{l}10 \% \text { glucose } \\
25 \% \text { glucose } \\
50 \% \text { glucose } \\
\text { EBM } \\
\text { Water }\end{array}$ & $\begin{array}{l}\text { Higher concentrations of glucose ( } 25 \% \text { and } 50 \% \text { ) more effectively reduced grimacing, crying } \\
\text { time, } \mathrm{HR} \text { increase and } \mathrm{O}_{2} \text { Sat decrease than } 10 \% \text { glucose and EBM ( } \mathrm{P}<0.05 \text { for all, except for } \\
\text { grimacing, for which } \mathrm{P} \text { value is not provided). } \\
\text { No significant differences between } 25 \% \text { and } 50 \% \text { glucose groups, or between } 10 \% \text { glucose and } \\
\text { EBM groups for all outcomes. }\end{array}$ \\
\hline $\begin{array}{l}\text { Okan et al (36), 2007; } \\
\text { n=31 preterm infants }\end{array}$ & $\begin{array}{l}20 \% \text { glucose } \\
20 \% \text { sucrose } \\
\text { Water }\end{array}$ & $\begin{array}{l}\text { Lower NFCS scores at } 4 \mathrm{~min}(\mathrm{P}=0.009) \text { and } 5 \mathrm{~min}(\mathrm{P}=0.046) \text { postlancing for glucose and } \\
\text { sucrose groups compared with water. } \\
\text { Lower HR values in glucose and sucrose groups compared with water at } 1 \text { min postlancing }(\mathrm{P}=0.007 \\
\text { No significant differences between the groups for crying time, respiration rate and } \mathrm{O}_{2} \mathrm{Sat} \text {. }\end{array}$ \\
\hline $\begin{array}{l}\text { Ramenghi et al (19), 2001; } \\
\quad \mathrm{n}=15 \text { infants }\end{array}$ & $\begin{array}{l}\text { Honey } \\
\text { Water }\end{array}$ & Reduced crying time for honey group compared with water group $(P=0.04)$ \\
\hline $\begin{array}{l}\text { Ramenghi et al (20), 1996; } \\
\mathrm{n}=60 \text { term infants }\end{array}$ & $\begin{array}{l}40 \% \text { maltitol } \\
50 \% \text { sucrose } \\
25 \% \text { sucrose } \\
\text { Water }\end{array}$ & $\begin{array}{l}\text { Lower modified NFCS scores for sweet solution groups at } 1 \text { min before lancing }(P=0.04) \text { and at } \\
3 \text { min postlancing }(P=0.05) \text {. } \\
\text { Lower HR increase for } 50 \% \text { sucrose and maltitol groups compared with water group }(P=0.009) \\
\text { Reduced crying time for all sweet solution groups compared with water }(P=0.02) \text {. }\end{array}$ \\
\hline $\begin{array}{l}\text { Skogsdal et al (48), 1997; } \\
\text { n=120 term and preterm }\end{array}$ & $\begin{array}{l}30 \% \text { glucose } \\
10 \% \text { glucose }\end{array}$ & $\begin{array}{l}\text { Lower HR increase for } 30 \% \text { glucose group compared with all other groups }(P<0.05) \text {. } \\
\text { Reduced incidence of cry for } 30 \% \text { glucose group }(P<0.01) \text { compared with all other groups. }\end{array}$ \\
\hline
\end{tabular}

No intervention

Venipuncture

Bauer et al (35), 2004;

$\mathrm{n}=58$ preterm infants

$30 \%$ glucose $(2 \mathrm{~mL})$

Lower PIPP scores for $2 \mathrm{~mL}$ glucose group compared with water $(\mathrm{P}=0.01)$.

$30 \%$ glucose $(0.4 \mathrm{~mL})$

Reduced crying time and incidence of cry for $2 \mathrm{~mL}$ glucose group compared with water $(P<0.05)$.

Water

Carbajal et al (22), 1999;

$30 \%$ glucose

$\mathrm{n}=150$ term infants

$30 \%$ sucrose

No significant differences in HR and oxygen consumption between groups.

$30 \%$ sucrose and sucking

Lower DAN scores for glucose group compared with water $(P=0.005)$ during venipuncture but higher DAN scores for glucose group compared with sucking $(P=0.0001)$.

Sucking

Water

No intervention

Carbajal et al (24), 2003;

$\mathrm{n}=179$ term infats

$30 \%$ glucose and sucking

Breast feeding

Water

No intervention

Deshmukh and Udani (39),

2002;

$10 \%$ glucose

$25 \%$ glucose

$\mathrm{n}=60$ preterm infants Water

Gharehbaghi and Ali (34), 2007; 25\% glucose

$\mathrm{n}=60$ term and preterm Water

infants

Gradin et al (31), 2002;

$\mathrm{n}=196$ preterm and term

infants

$30 \%$ glucose

$2.5 \%$ lidocaine $/ 2.5 \%$ prilocaine cream

Gradin et al (41), 2004; $\mathrm{n}=111$ term infants

$30 \%$ glucose

$30 \%$ glucose and

breastfeeding

Breastfeeding and water

Water

Ling et al (42), 2005;

$\mathrm{n}=52$ term infants

Liu et al (60), 2010;

$\mathrm{n}=105$ term and preterm

$30 \%$ glucose

Water

$25 \%$ glucose

Sucking

infants

No intervention

Shadkam and Lofti (46), 2008; 30\% glucose and placebo $\mathrm{n}=220$ term infants cream

Water and $2.5 \%$ lidocaine/2.5\% prilocaine cream
No other comparison with glucose group was made

Lower DAN scores and PIPP scores for glucose group compared with water $(P<0.0001)$.

No significant differences among glucose and sucking compared with breastfeeding groups for DAN or PIPP.

No significant differences in $\mathrm{HR}, \mathrm{O}_{2}$ Sat and respiratory rate between groups.

Reduced crying time for $25 \%$ glucose compared with control $(P=0.002)$ and $10 \%$ glucose $(P=0.002)$.

No significant differences in crying time between $10 \%$ glucose and water groups $(P=0.23)$.

Lower CRIES scores for glucose group compared with water $(P=0.0001)$.

Reduced crying time for glucose group compared with water $(P=0.0001)$.

No significant differences in HR after puncture between the groups.

Lower PIPP scores in glucose group compared with $2.5 \%$ lidocaine/2.5\% prilocaine cream $(P=0.0314)$.

No significant differences for changes in HR between groups.

Reduced crying time for glucose group compared with $2.5 \%$ lidocaine/2.5\% prilocaine cream $(\mathrm{P}<0.0001)$.

Lower PIPP scores for glucose with or without breastfeeding compared with breastfeeding and water or water groups $(P=0.004)$.

Reduced crying time in breastfeeding and glucose group compared with breastfeeding and water $(P=0.008)$, glucose $(P=0.022)$ and water $(P \leq 0.001)$ groups.

Reduced crying time for glucose compared with water groups $(\mathrm{P}=0.009)$.

Lower NIPS scores for glucose group compared with water $(P=0.03)$.

Reduced crying time for glucose group compared with water $(P=0.03)$.

Lower NIPS scores for glucose group compared with water $(\mathrm{P}=0.005)$.

Sucking was more effective than glucose $(P<0.017)$.

Lower NIPS scores for glucose group compared with water and 2.5\% lidocaine/2.5\% prilocaine cream $(P<0.001)$.

Reduced crying time for glucose group compared with water and $2.5 \%$ lidocaine/2.5\% prilocaine cream $(P<0.01)$. 
TABLE 1 - CONTINUED

\section{Characteristics of included studies}

\begin{tabular}{|c|c|c|}
\hline Author (reference), year; $n$ & Comparison groups & Outcome measures and main results \\
\hline \multicolumn{3}{|l|}{ Heel lance and venipuncture } \\
\hline $\begin{array}{l}\text { Eriksson et al (49), 1999; } \\
n=120 \text { term infants }\end{array}$ & $\begin{array}{l}30 \% \text { glucose } \\
\text { No intervention }\end{array}$ & $\begin{array}{l}\text { Lower PIPP scores during heel lance }(P<0.0001) \text { and venipuncture }(P<0.0241) \text { for glucose group } \\
\text { compared with water. } \\
\text { Higher increase in HR for glucose group compared with water, for both procedures }(P=0.0201) \text {. } \\
\text { Reduced crying time for glucose group versus water for heel lance }(P<0.0001) \text { but not } \\
\text { venipuncture. }\end{array}$ \\
\hline
\end{tabular}

Heel lance and pharyngeal suctioning

\begin{tabular}{|c|c|c|}
\hline $\begin{array}{l}\text { Axelin et al (51), } 2009 \\
n=20 \text { preterm infants }\end{array}$ & $\begin{array}{l}24 \% \text { glucose } \\
\text { Facilitated tucking } \\
\text { Oxycodone } \\
\text { Water }\end{array}$ & $\begin{array}{l}\text { Lower PIPP scores for the glucose group compared with water during heel lance }(P \leq 0.001) \text { and } \\
\text { pharyngeal suctioning }(P=0.014) \text {. No comparison between glucose and other groups. } \\
\text { No significant differences in NIPS scores of glucose group compared with water during heel } \\
\text { lance }(P=0.072) \text { and pharyngeal suctioning }(P=0.642) \text {. No comparisons between glucose and } \\
\text { other groups. }\end{array}$ \\
\hline
\end{tabular}

Intramuscular injection

\begin{tabular}{|c|c|c|}
\hline $\begin{array}{l}\text { Chermont et al (52), 2009; } \\
n=640 \text { term infants }\end{array}$ & $\begin{array}{l}25 \% \text { glucose } \\
\text { Skin to skin contact } \\
\text { Skin to skin contact and } 25 \%\end{array}$ & $\begin{array}{l}\text { Lower NFCS, NIPS and PIPP scores for skin-to-skin contact and } 25 \% \text { glucose group compared } \\
\text { with each intervention alone and no intervention group }(P<0.001 \text { for each comparison). } \\
\text { Skin to skin contact superior to } 25 \% \text { glucose group in reducing NFCS and NIPS }(P=0.045) \text {. }\end{array}$ \\
\hline
\end{tabular}
glucose No intervention

Golestan et al (45), 2007; $\mathrm{n}=90$ term infants

Sajedi et al (33), 2006;

$\mathrm{n}=64$ term infants Subcutaneous injection Carbajal et al (23), 2002; $\mathrm{n}=39$ preterm infants
$50 \%$ glucose

Water

No intervention

$30 \%$ glucose

Water
No significant differences in HR between glucose and the other groups.

Reduced crying time for glucose group compared with no intervention $(P=0.0001)$ but not compared with water $(\mathrm{P}=0.191)$.

Lower NIPS scores for glucose group compared with water $(P=0.001)$ No significant differences in HR between groups.

Eye examination for retinopathy of prematurity

\begin{tabular}{|c|c|c|}
\hline $\begin{array}{l}\text { Olsson and Eriksson (53), } \\
2011 ; n=30 \text { preterm infants } \\
\text { Circumcision }\end{array}$ & $\begin{array}{l}30 \% \text { glucose } \\
\text { Water }\end{array}$ & No significant differences in PIPP scores, cry, $\mathrm{HR}$ or $\mathrm{O}_{2}$ Sat between groups. \\
\hline $\begin{array}{l}\text { Kass and Holman (32), 2001; } \\
\mathrm{n}=71 \text { infants }\end{array}$ & $\begin{array}{l}50 \% \text { glucose } \\
\text { DPNB } \\
\text { Water }\end{array}$ & $\begin{array}{l}\text { Results favoured DPNB group compared with water or glucose groups for MBPS scores } \\
(P<0.001), \mathrm{HR} \text { increase }(P=0.005), \mathrm{O}_{2} \text { Sat }(P=0.03) \text { and cry duration }(P=0.001) \text {. }\end{array}$ \\
\hline \multicolumn{3}{|c|}{ Peripherally inserted central catheter } \\
\hline $\begin{array}{l}\text { Michel et al (26), 2010; } \\
\mathrm{n}=59 \text { term and preterm } \\
\text { infants }\end{array}$ & $\begin{array}{l}\text { Sevoflurane } \\
30 \% \text { glucose and pacifier }\end{array}$ & $\begin{array}{l}\text { Higher occurrence of bradycardia }(P=0.02) \text {, tachycardia }(P<0.001) \text { and hypertension }(P=0.003) \\
\text { for the glucose group. No significant differences on hypotension, } \mathrm{O}_{2} \text { Sat or episodes of apnea. } \\
\text { Higher occurrence of body movements for the glucose group }(\mathrm{P}<0.017) \text {. }\end{array}$ \\
\hline
\end{tabular}

CRIES Crying, Requires oxygen, Increased vital signs, Expression, Sleepless; DAN Douleur Aigue du Nouveau-Né; DPNB Dorsal penile nerve block; EMB Expressed breast milk; HR Heart rate; IBCS Infant Body Coding System; MBPS Modified Behavioural Pain Scale; NIPS Neonatal Infant Pain Scale; NFCS Neonatal Facial Coding System; $\mathrm{O}_{2}$ Sat Oxygen saturation; PIPP Premature Infant Pain Profile; SS Sensorial saturation

Problems were most frequently related to appropriate generation of a randomization sequence $(17,19,20,25-27,33,37-47)$, allocation concealment $(17,19,20,25-27,29,30,32-34,37-42,46-50)$ and blinding $(19,20,22,23,25-30,32,33,37-40,42,44,51,52)$. Blinding difficulties were commonly related to comparison interventions that precluded blinding, eg, breast feeding, non-nutritive sucking, skin to skin contact and inhaled sevoflurane.

In fewer trials, a risk for selective outcome reporting was identified $(17,19,27,29,32,45)$. There was not enough information on incomplete outcome data in one trial (19) and risk of other sources of bias in four studies $(19,26,46,53)$

Efficacy of nonsucrose solutions for painful procedures

Heel lance: Pain scores: Validated pain assessment tools were used to measure pain during heel lance in 14 studies. Six studies $(27,44,47,49-51)$ used the Premature Infant Pain Profile (PIPP) (54); three trials $(17,20,36)$ used the Neonatal Facial Coding System (NFCS) (55) and its subsets; three studies $(18,21,29)$ used the Douleur Aiguë du Nouveau Né (DAN) scale (56); and three $(43,47,51)$ used the Neonatal Infant Pain Scale (NIPS) (57). The
Body Pain Score (58) and the ABC scale (59) were used in one study each $(17,25)$.

Glucose $(0.2 \mathrm{~mL}$ to $2 \mathrm{~mL}$ of $10 \%$ to $50 \%$ solution) versus no intervention or water significantly reduced pain scores during and/or after heel lances $(18,21,27,36,43,49)$. The administration of artificial sweetener (17), maltitol (20) and fructose (18) reduced pain scores compared with no intervention or water.

Results from two of the six RCTs that used the PIPP to assess pain during heel lancing were included in a meta-analysis. A 3.6-point reduction in PIPP scores during and/or after heel lances was observed for $20 \%$ to $30 \%$ glucose ( $1 \mathrm{~mL}$ to $2 \mathrm{~mL}$ ) compared with no intervention $(49,50)(124$ neonates; MD -3.61 [95\% CI -4.58 to -2.63 ]; $\mathrm{P}<0.001 ; \mathrm{I}^{2}=54 \%$ ) (Figure 2).

Two trials used the NIPS and the PIPP to assess the same heel lance $(47,51)$. Bonetto et al $(47)$ reported no differences in PIPP scores, while NIPS scores significantly favoured $25 \%$ glucose $(1 \mathrm{~mL})$ versus $2.5 \%$ lidocaine $2.5 \%$ prilocaine cream, acetaminophen or water. Axelin et al (51) reported significantly lower PIPP scores for neonates receiving $24 \%$ glucose $(0.2 \mathrm{~mL})$ versus water $(0.2 \mathrm{~mL})$ but reported no differences in NIPS scores. 


\begin{tabular}{|c|c|c|c|c|c|c|c|c|c|c|}
\hline \multirow[b]{2}{*}{ Study or Subgroup } & \multicolumn{3}{|c|}{ Experimental } & \multicolumn{3}{|c|}{ Control } & \multicolumn{2}{|c|}{ Mean Difference } & \multirow{2}{*}{\multicolumn{2}{|c|}{$\begin{array}{l}\text { Mean Difference } \\
\text { IV. Fixed, } 95 \% \mathrm{Cl}\end{array}$}} \\
\hline & Mean & SD & Total & Mean & SD & Total & Weight & IV, Fixed, $95 \% \mathrm{CI}$ & & \\
\hline Eriksson 1999 & 3.9 & 2.6 & 30 & 8.4 & 3.4 & 30 & $40.6 \%$ & $-4.50[-6.03,-2.97]$ & $\rightarrow-$ & \\
\hline F reire 2008 & 7.93 & 2.69 & 31 & 10.93 & 2.46 & 33 & $59.4 \%$ & $-3.00[-4.27,-1.73]$ & -1 & \\
\hline Total $(95 \% \mathrm{Cl})$ & & & 61 & & & 63 & $100.0 \%$ & $-3.61[-4.58,-2.63]$ & $>$ & \\
\hline $\begin{array}{l}\text { Heterogeneity: } \mathrm{Chi}^{2}= \\
\text { Test for overall effect: }\end{array}$ & $\begin{array}{l}2.19, \text { df }= \\
z=7.25\end{array}$ & $\begin{array}{l}=1(P=) \\
(P<0 .\end{array}$ & $\begin{array}{l}=0.14) ; \\
00001)\end{array}$ & $i^{2}=549$ & & & & & $\begin{array}{lll}-10 & -5 & 0 \\
\text { avours } & -5 & 0\end{array}$ & 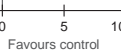 \\
\hline
\end{tabular}

Figure 2) Mean Premature Infant Pain Profile scores after heel lancing for infants receiving $20 \%$ to $30 \%$ glucose ( $1 \mathrm{~mL}$ to $2 \mathrm{~mL}$ ) compared with no intervention

In the one trial that compared $20 \%$ glucose and sucrose $(2 \mathrm{~mL})$ solutions (36), differences in NFCS scores were not significant. These results suggest similar effectiveness of both glucose and sucrose.

Physiological outcomes: HR was assessed at various intervals of time in 11 studies. Three trials reported significantly lower increases in HR for infants receiving $10 \%$ to $50 \%$ glucose ( $1 \mathrm{~mL}$ to $2 \mathrm{~mL}$ ) compared with water or no intervention during and after heel lance $(36,40,48)$. Ramenghi et al (20) reported significantly lower increases in HR for maltitol compared with the water group.

A significant increase in HR was reported by Eriksson et al (49) among infants receiving 30\% glucose versus no intervention and by Guala et al (28) when comparing $5 \%$ glucose with $30 \%$ glucose and water.

Three trials (36-38) reported no significant changes in HR after heel lancing between infants receiving $2 \mathrm{~mL}$ of glucose or $2 \mathrm{~mL}$ sucrose (5\% to $50 \%)$.

HR data at 3 min post-heel lance were combined in two meta-analyses for infants who received $33 \%$ glucose $(2 \mathrm{~mL})$ versus no intervention and water $(28,37)$. No statistically significant differences between the groups were observed (glucose versus no intervention: 69 infants; MD 3.68 [95\% CI -3.98 to 11.33 ]; $\mathrm{P}=0.35 ; \mathrm{I}^{2}=0 \%$; glucose versus water: 74 infants; MD 5.61 [95\% CI -1.95 to 13.17 ]; $\mathrm{P}=0.15 ; \mathrm{I}^{2}=0 \%$ ).

HR data at $3 \mathrm{~min}$ post-heel lance were combined from two studies in which $50 \%$ glucose solution $(2 \mathrm{~mL})$ was administered $(28,43)$. There were no statistically significant differences in HR between glucose groups compared with no intervention ( 80 neonates; MD 3.26 [95\% $\mathrm{CI}-7.32$ to 13.84$\left.], \mathrm{P}=0.55, \mathrm{I}^{2}=0 \%\right)$ or water ( 80 neonates; $\mathrm{MD}-4.06$ [95\% CI -14.28 to 6.16], $\mathrm{P}=0.44, \mathrm{I}^{2}=84 \%$ ).

No significant differences were observed between glucose and control groups regarding $\mathrm{O}_{2}$ Sat and $\mathrm{RR}(36,43)$, with the exception of one study that reported a lower $\mathrm{O}_{2}$ Sat reduction from baseline for infants receiving $10 \%$ to $50 \%$ glucose compared with water (40). Okan et al (36) described no differences in $\mathrm{O}_{2}$ Sat and RR for $20 \%$ glucose and sucrose groups.

Cry behaviour: Glucose ( $1 \mathrm{~mL}$ to $2 \mathrm{~mL}$ of $10 \%$ to $50 \%$ solution) significantly decreased cry duration when compared with water or no intervention in four trials $(30,40,48,49)$; however, no significant differences between glucose and no intervention or water groups were reported in three trials $(36,38,43)$.

When data were pooled $(40,43), 1 \mathrm{~mL}$ to $2 \mathrm{~mL}$ of $50 \%$ glucose significantly reduced total duration of crying compared with water ( $1 \mathrm{~mL}$ to $2 \mathrm{~mL}$ ) (90 newborns; $\mathrm{MD}-36.40$ [95\% CI -43.27 to -29.54$]$; $\left.\mathrm{P}<0.001 ; \mathrm{I}^{2}=0 \%\right)$.

A longer duration of crying within $3 \mathrm{~min}$ after heel lance was described for neonates receiving $10 \%$ or $30 \%$ glucose compared with $30 \%$ sucrose (38), although no significant differences in crying characteristics were observed by Okan et al (36) between 20\% glucose and sucrose groups.

A significant reduction in crying was observed in neonates receiving maltitol (20), artificial sweetener (17) and honey (19) compared with water.

Venipuncture: Pain scores: Four validated pain assessment tools were used: the PIPP $(24,31,35,41,49)$, the DAN $(22,24)$ and the NIPS $(42,46,60)$ scales, as well as the Crying; Requires increased oxygen administration; Increased vital signs; Expression; Sleeplessness (CRIES) scale $(34,61)$.

All 11 studies in which $25 \%$ to $50 \%$ glucose ( $1 \mathrm{~mL}$ to $2 \mathrm{~mL}$ ) was administered demonstrated significant reduction in pain scores compared with $10 \%$ glucose, water, no intervention or $2.5 \%$ lidocaine $/ 2.5 \%$ prilocaine cream. However, Liu et al (60) described

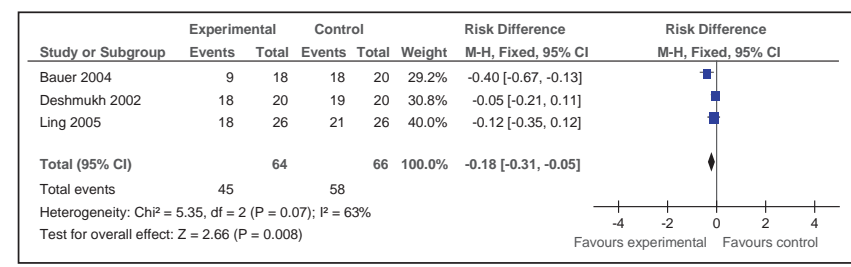

Figure 3) Incidence of crying after venipuncture for infants receiving $25 \%$ to $30 \%$ glucose $(1 \mathrm{~mL}$ to $2 \mathrm{~mL}$ ) compared with water

lower NIPS scores for infants receiving sucking compared with 25\% glucose.

Carbajal et al (22) described similar DAN scores for $2 \mathrm{~mL}$ of $30 \%$ glucose and sucrose groups after venipuncture.

Physiological outcomes: HR was assessed in five trials involving venipuncture. No significant differences in HR responses were observed in infants receiving $10 \%$ to $30 \%$ glucose compared with water $(34,35,39)$ or $2.5 \%$ lidocaine $2.5 \%$ prilocaine cream (31). An increased HR in infants receiving $30 \%$ glucose was reported in one trial (49).

Data from two studies $(34,39)$ assessing HR at 5 min after venipuncture were pooled. No significant differences were found between $2 \mathrm{~mL}$ of $25 \%$ glucose versus water groups (100 infants; MD 0.26 [95\% CI -5.79 to 6.32 ]; $\left.\mathrm{P}=0.93 ; \mathrm{I}^{2}=79 \%\right)$. There were no significant changes in $\mathrm{O}_{2}$ Sat, oxygen consumption or $\mathrm{RR}(35,39)$.

Cry behaviour: Eight studies included crying behaviour as an outcome measure. For various intervals of time spent crying after venipuncture, results favoured $25 \%$ to $30 \%$ glucose ( $1 \mathrm{~mL}$ to $2 \mathrm{~mL}$ ) compared with water or no intervention $(34,35,39,41,42)$. No differences were reported by Eriksson et al (49) when comparing $1 \mathrm{~mL}$ of $30 \%$ glucose with no intervention. Gradin et al (31) and Shadkam et al (46) reported results favouring $30 \%$ glucose $(1 \mathrm{~mL})$ versus $2.5 \%$ lidocaine/2.5\% prilocaine cream for crying time after venipuncture. When data were pooled $(34,39), 25 \%$ glucose $(2 \mathrm{~mL})$ significantly reduced total duration of crying after venipuncture compared with water ( 100 neonates; $M D-14.57 \mathrm{~s}$ [95\% CI -17.61 to -11.53 ]; $\mathrm{P}<0.001 ; \mathrm{I}^{2}=82 \%$ ).

Incidence of cry after venipuncture was reduced among infants receiving $25 \%$ to $30 \%$ glucose ( $1 \mathrm{~mL}$ to $2 \mathrm{~mL}$ ) versus water after combining results of three studies $(35,39,42)$ (relative risk $0.80[95 \% \mathrm{CI} 0.66$ to 0.96 ], $\mathrm{P}=0.02$ and $\mathrm{RD}-0.18$ [95\% CI -0.31 to -0.05 ]; $\mathrm{P}=0.008$, number needed to treat $=6[95 \%$ CI 3 to 20$] ; I^{2}=63 \%$ ) (Figure 3 ).

Intramuscular injections: Significantly lower NIPS scores were reported in one study for neonates receiving $30 \%$ glucose $(2 \mathrm{~mL}) \mathrm{com}$ pared with water at $3 \mathrm{~min}$ after injection (33), but Chermont et al (52) reported no differences in pain scores (NFCS, NIPS or PIPP) for $25 \%$ glucose versus no intervention. There were no significant differences for changes in HR among 30\% to 50\% glucose, water and no intervention groups $(33,45)$.

Subcutaneous injections: Carbajal et al (23) described significantly lower DAN scores for infants who received $30 \%$ glucose $(0.3 \mathrm{~mL})$ compared with water during subcutaneous injections.

PICC placement: A single trial investigated the effects of $0.2 \mathrm{~mL}$ of $30 \%$ glucose and sucking compared with sevoflurane during PICC placement (26). All infants included in the trial required assisted ventilation and received $2.5 \%$ lidocaine $/ 2.5 \%$ prilocaine cream before puncture. Results indicate that the glucose and sucking group presented higher incidence of bradycardia, tachycardia and hypertension than the sevoflurane group. Body movements were increased for the glucose group.

Eye examination for retinopathy of prematurity: No significant differences were reported in PIPP scores, cry, HR and $\mathrm{O}_{2}$ Sat between infants who received $30 \%$ glucose or water $(1 \mathrm{~mL})$ before eye examination for retinopathy of prematurity (53).

Circumcision: No differences in Modified Behavioural Pain Scale (MBPS) (62) scores, $\mathrm{HR}, \mathrm{O}_{2}$ Sat and cry were observed for infants receiving $50 \%$ glucose and water before circumcision (32). 
Pharyngeal suctioning: Axelin et al (51) reported significantly lower PIPP scores for neonates receiving $24 \%$ glucose $(0.2 \mathrm{~mL})$ versus water, but no significant differences for NIPS scores.

\section{Adverse events}

Thirteen trials recorded possible adverse events related to the solutions $(18,21,23,26,28,31,34,37,39,42,46,51,52)$. Carbajal et al (23) reported one death from necrotizing enterocolitis in an infant who received water and seven episodes of oxygen desaturation (five in neonates receiving $0.3 \mathrm{~mL}$ of $30 \%$ glucose and two in neonates receiving glucose plus pacifier). No adverse events were reported for infants receiving water. Axelin et al (51) reported short-term desaturation and/or bradycardia episodes in $21 \%$ of infants receiving $0.2 \mathrm{~mL}$ of $24 \%$ glucose, and in $12.5 \%$ of the infants receiving water. No adverse events related to the administration of sweet solutions were recorded in the other 11 studies.

\section{DISCUSSION}

The increasing interest in exploring the analgesic properties of orally administered glucose for pain relief over other sugars may be explained by its availability in clinical settings for intravenous use $(22,32,38,40,42,48)$. Manufactured sucrose may not always be readily available or institutions may not be equipped with pharmacies to prepare sucrose solutions; therefore, the efficacy of alternative sweet solutions, such as glucose, as analgesic strategies for painful procedures in neonates needs to be determined.

To our knowledge, the present systematic review and meta-analyses are the first to evaluate the efficacy of nonsucrose sweet-tasting solutions during painful procedures in neonates. The large number of trials included (38 RCTs; 3785 neonates) and the results of the meta-analyses contribute to strengthen the present review. A recently published systematic review by Kassab et al (63) investigated the analgesic effects of glucose during needle-related pain in infants younger than 12 months of age. The authors included 18 studies and no meta-analyses were conducted. Differences may be explained by search strategies, assessment of study quality adopted and by the age of included infants because Kassab et al (63) excluded studies involving preterm infants.

The assessment of risk of bias is dependent on the authors' report of methodological details of their study. Efforts were made to contact the authors and, in some cases, additional information on randomization processes, allocation concealment techniques, blinding and losses, among others, was provided. In addition, methodological discrepancies were observed across the included studies, especially regarding the variety of volumes and concentration of glucose solutions and the outcome measures.

The results of the present systematic review and meta-analyses indicate lower pain scores for neonates receiving glucose compared with water or no intervention for heel lances and venipuncture. These findings are similar to those reported by Stevens et al (9) in a systematic review and meta-analysis on the effectiveness of sucrose solution for pain relief in neonates, emphasizing that glucose is an effective alternative to sucrose.

The results of single trials demonstrated the analgesic effects of glucose during other minor skin-breaking procedures (subcutaneous injections [23], intramuscular injections [33] and pharyngeal suctioning [51]). Additional studies are warranted to confirm the efficacy of glucose during these procedures. Conversely, glucose did not provide adequate analgesia during circumcision (32) and eye examination (53). Procedures of longer duration may require additional pharmacological and nonpharmacological interventions to be effective (9) and further investigation is needed.

Pain scores were the most commonly reported outcome measure. A meta-analysis including 124 infants demonstrated that $1 \mathrm{~mL}$ to $2 \mathrm{~mL}$ of a $20 \%$ to $30 \%$ glucose solution compared with no intervention effectively reduced PIPP scores during the first $30 \mathrm{~s}$ after heel lancing. Eriksson et al (49) included healthy term infants, whereas Freire et al (50) enrolled healthy preterm neonates. Differences among the facial expression of term and preterm infants undergoing painful procedures are well described in the literature $(58,64,65)$. These differences may have been minimized between these trials due to the use of the PIPP to assess pain. The PIPP is a validated, composite multidimensional pain score that considers gestational age as a modifying factor on pain expression in infants. Outcome measurement procedures and procedure technique may have contributed to high between-study heterogeneity. These findings are consistent with the meta-analyses reported in a systematic review on the effectiveness of sucrose on PIPP scores of infants undergoing heel lancing (9).

Although PIPP scores were considered the primary outcome in four other studies $(27,44,47,51)$, differences in the intervention, especially volume and concentration of glucose solution, and comparison interventions used, precluded their inclusion in meta-analysis.

Additional meta-analyses showed significant mean reductions in crying behaviours during and after heel lancing (reduction of $36.4 \mathrm{~s}$ ) or venipuncture (reduction of $14.6 \mathrm{~s}$ ) for neonates receiving $25 \%$ to $50 \%$ glucose solutions compared with water or no intervention. Incidence of crying after venipuncture was reduced by $20 \%$ for infants receiving $25 \%$ to $30 \%$ glucose after venipuncture compared with water. Methodological discrepancies may contribute to between-study heterogeneity, especially regarding definitions of crying behaviour, outcome measurement procedures and procedural technique.

A statistically significant reduction in the total duration of crying was reported when comparing sucrose solution with water for infants undergoing heel lances, although no differences were observed for duration of first cry when comparing neonates receiving sucrose and water during lancing (9). Crying behaviour was significantly reduced by the administration of glucose or sucrose before immunization in infants between one and 12 months of age (66).

A relatively small number of infants were included in each metaanalysis, and moderate to high between-study heterogeneity can be observed in some cases. However, these results can be considered to be clinically significant in favour of glucose for heel lances and venipunctures.

Physiological indicators were not significantly affected by the administration of $25 \%$ to $50 \%$ glucose, which is similar to the results of sucrose administration as reported in a systematic review (9). Although physiological indexes are important indicators of neonatal pain, lack of specificity may explain these results.

In one trial, an increase in HR was observed for infants receiving $30 \%$ glucose compared with no intervention (49). The effects of $30 \%$ glucose on increasing HR were later confirmed by Gradin (67) in a trial that involved healthy term infants with no painful intervention. A possible explanation provided by the author is an increased awareness caused by the sweet taste as well as an increase in sympaticus activation.

The administration of sweet solutions in combination with nonnutritive sucking were commonly reported. The analgesic and calming effects of sucking are mainly explained by the stimulation of orogustatory and mechanoreceptors due to the sucking action (68). However, it remains unclear whether there are additive or synergistic effects when sweet solutions and sucking are combined (69). Overall, most included studies identified positive effects of combining both interventions for term and preterm infants undergoing heel lances and venipuncture.

Glucose combined with sensorial saturation was described as more effective than glucose and sucking for analgesia during heel lances. However, sensorial saturation without glucose was not effective and the authors reported that sensorial saturation caused increased awareness and irritation in the infants (29). Further investigation regarding the efficacy and safety of sensorial saturation is required before clinical practice recommendations can be made. Breastfeeding (41) and skin to skin contact (52) combined with glucose were reported to be more effective as pain-reducing interventions than glucose alone. The effects of combining these interventions with sweet solutions should be further investigated. 
Several trials included placebo and/or no intervention groups. In some cases, both water and no intervention were compared with an experimental intervention $(22,24,28,37,43,45)$. The results of the present review, combined with results reported by Stevens et al (9) and Harrison et al (66), provide strong and consistent evidence for the analgesic efficacy of sweet-tasting solutions during single procedures in healthy term and preterm infants. Therefore, researchers should consider including sweet-tasting solution as the control intervention in future studies involving this population.

Short-term effects of glucose administration (bradycardia and desaturation) were reported in two studies that enrolled very preterm neonates. There were no differences in adverse event rates between the glucose and water groups, and these events were explained as being more related to the neonate's ability to swallow rather than the type of solution (51).

Overall, results indicate no significant differences in the effects of glucose and sucrose solutions, although the limited number of studies comparing the two solutions precluded meta-analysis. Further research is required to establish the comparative efficacy of these solutions.

With the exception of Michel et al (26), studies included in the present review did not investigate the effects of nonsucrose sweet

\section{REFERENCES}

1. Blass E, Fitzgerald E, Kehoe P. Interactions between sucrose, pain and isolation distress. Pharmacol Biochem Behav 1987;26:483-9.

2. Blass EM, Shah A. Pain-reducing properties of sucrose in human newborns. Chem Senses 1995;20:29-35.

3. Ren K, Blass EM, Zhou QQ, Dubner R. Suckling and sucrose ingestion suppress persistent hyperalgesia and spinal fos expression after forepaw inflammation in infant rats. Proc Natl Acad Sci USA 1997;94:1471-75.

4. Blass EM, Smith BA. Differential effects of sucrose, fructose, glucose, and lactose on crying in 1- to 3-day-old human infants: Qualitative and quantitative considerations. Dev Psychol 1992;28:804-10.

5. Anand KJ, International Evidence-Based Group for Neonatal Pain. Consensus statement for the prevention and management of pain in the newborn. Arch Pediatr Adolesc Med 2001;155:173-80.

6. Royal Australasian College of Physicians. Guideline Statement: Management of Procedure-related Pain in Neonates. Sydney: Paediatrics \& Child Health Division, The Royal Australasian College of Physicians; 2005. <www.racp.edu.au> (Accessed January 31, 2012).

7. American Academy of Pediatrics Committee on Fetus and Newborn, American Academy of Pediatrics Section on Surgery, Canadian Paediatric Society Fetus and Newborn Committee, Batton DG, Barrington KJ, Wallman C. Prevention and management of pain in the neonate: An update. Pediatrics 2006;118:2231-41.

8. Lago P, Garetti E, Merazzi D, et al. Guidelines for procedural pain in the newborn. Acta Paediatr 2009;98:932-9.

9. Stevens B, Yamada J, Ohlsson A. Sucrose for analgesia in newborn infants undergoing painful procedures. Cochrane Database Syst Rev 2010(1):CD001069.

10. Higgins JPT, Green S. Cochrane Handbook for Systematic Reviews of Interventions Version 5.0.1 [updated March 2011]. The Cochrane Collaboration. <www.cochrane-handbook.org/> (Accessed January 31, 2012).

11. Review Manager (RevMan) Version 5.0. Copenhagen: The Nordic Cochrane Centre, The Cochrane Collaboration, 2008.

12. Moher D, Liberati A, Tetzlaff J, Altman DG, PRISMA Group. Preferred reporting items for systematic reviews and meta-analyses: The PRISMA statement. BMJ 2009;339:b2535.

13. Ahuja VK, Daga SR, Gosavi DV, Date AM. Non-sucrose sweetener for pain relief in sick newborns. Indian J Pediatr 2000;67:487-9.

14. Akman I, Zek E, Bilgen H, Ozdogan T, Cebeci D. Sweet solutions and pacifiers for pain relief in newborn infants. J Pain 2002;3:199-202.

15. Askarpour S, Dehdashtian M, Marashi S. Effect of oral glucose and the response to pain in the term neonate. Pak J Med Sci 2007;23:733-35.

16. Idam-Siuriun DI, Zhirkova I, Mikhel'son VA, Sepbaeva AD. Prevention of pain during finger prick in neonatal infants. Anesteziol Reanimatol 2008;1:14-7.

17. Bucher HU, Baumgartner R, Bucher N, Seiler M, Fauchere JC. Artificial sweetener reduces nociceptive reaction in term newborn infants. Early Hum Dev 2000;59:51-60. solutions in critically ill infants, although this population undergoes multiple painful procedures during prolonged hospitalizations $(70,71)$. No studies measured the effects of repeated doses of glucose for procedural pain. Further investigation is needed to establish the efficacy and safety of nonsucrose solutions in both situations.

\section{CONCLUSION}

A substantial variability in the volumes and concentrations of glucose solutions administered and the large variety in outcome measurements precluded further meta-analysis. However, the large number of included studies contributes to the strength of the present systematic review.

Overall, results indicate that $20 \%$ to $30 \%$ glucose solutions have analgesic effects on both term and preterm neonates undergoing a single heel lance and venipuncture and can, therefore, be recommended as an alternative to sucrose for procedural pain reduction in this population.

FUNDING: Canadian Institutes of Health Research (CIHR) Systematic Review of Sweet Solutions for Acute Pain Relief in Infants Knowledge Synthesis Team (KRS91774). CIHR Strategic Training in Health Research Pain in Child Health (PICH) Initiative (STP53885). CIHR Team Grant in Children's Pain (CTP-79854 and MOP-86605)

18. Akcam M. Oral fructose solution as an analgesic in the newborn: A randomized, placebo-controlled and masked study. Pediatr Int 2004;46:459-62.

19. Ramenghi LA, Amerio G, Sabatino G. Honey, a palatable substance for infants: From De Rerum Natura to evidence-based medicine. Eur J Pediatr 2001;160:677-8.

20. Ramenghi LA, Griffith GC, Wood CM, Levene MI. Effect of nonsucrose sweet tasting solution on neonatal heel prick responses. Arch Dis Child Fetal Neonatal Ed 1996;74:F129-31.

21. Akcam M, Ormeci AR. Oral hypertonic glucose spray: A practical alternative for analgesia in the newborn. Acta Paediatr 2004;93:1330-3.

22. Carbajal R, Chauvet X, Couderc S, Olivier-Martin M. Randomised trial of analgesic effects of sucrose, glucose, and pacifiers in term neonates. BMJ 1999;319:1393-7.

23. Carbajal R, Lenclen R, Gajdos V, Jugie M, Paupe A. Crossover trial of analgesic efficacy of glucose and pacifier in very preterm neonates during subcutaneous injections. Pediatrics 2002;110:389-93.

24. Carbajal R, Veerapen S, Couderc S, Jugie M, Ville Y. Analgesic effect of breast feeding in term neonates: Randomised controlled trial. BMJ 2003;326:13.

25. Bellieni CV, Cordelli DM, Marchi S, et al. Sensorial saturation for neonatal analgesia. Clin J Pain 2007;23:219-21.

26. Michel F, Vialet R, Hassid S et al. Sevoflurane for central catheter placement in neonatal intensive care: A randomized trial. Paediatr Anaesth 2010;20:712-9.

27. Bellieni CV, Buonocore G, Nenci A, Franci N, Cordelli DM, Bagnoli F. Sensorial saturation: An effective analgesic tool for heel-prick in preterm infants: A prospective randomized trial. Biol Neonate 2001;80:15-8.

28. Guala A, Pastore G, Liverani ME, et al. Glucose or sucrose as an analgesic for newborns: A randomised controlled blind trial. Minerva Pediatr 2001;53:271-4.

29. Bellieni CV, Bagnoli F, Perrone S, et al. Effect of multisensory stimulation on analgesia in term neonates: A randomized controlled trial. Pediatr Res 2002;51:460-3.

30. Bellieni CV, Bagnoli F, Cordelli DM, Perrone S, Nenci A, Buonocore G. Analgesia for premature children. Italian J Ped 2003;29:286-90.

31. Gradin M, Eriksson M, Holmqvist G, Holstein A, Schollin J. Pain reduction at venipuncture in newborns: Oral glucose compared with local anesthetic cream. Pediatrics 2002;110:1053-7.

32. Kass FC, Holman JR. Oral glucose solution for analgesia in infant circumcision. J Fam Pract 2001;50:785-8.

33. Sajedi F, Kashaninia Z, Rahgozar M, Radrazm L. The efficacy of oral glucose for relieving pain following intramuscular injection in term neonates. Acta Med Iran 2006;44:316-22.

34. Gharehbaghi MM, Ali P. The effect of oral dextrose on pain relief of newborn infants. Pakistan J Med Sci 2007;23:881-4.

35. Bauer K, Ketteler J, Hellwig M, Laurenz M, Versmold H. Oral glucose before venepuncture relieves neonates of pain, but stress is still evidenced by increase in oxygen consumption, energy expenditure, and heart rate. Pediatr Res 2004;55:695-700. 
36. Okan F, Coban A, Ince Z, Yapici Z, Can G. Analgesia in preterm newborns: The comparative effects of sucrose and glucose. Eur J Pediatr 2007;166:1017-24.

37. Guala A, Giroletti G. Glucose as an analgesic in neonatology. A blind randomized controlled study. Pediatr Med Chir 1998;20:201-3.

38. Isik U, Ozek E, Bilgen H, Cebeci D. Comparison of oral glucose and sucrose solutions on pain response in neonates. J Pain 2000;1:275-78.

39. Deshmukh LS, Udani RH. Analgesic effect of oral glucose in preterm infants during venipuncture: A double blind, randomized, controlled trial. J Trop Ped 2002;48:138-41.

40. Jatana SK, Dalal SS, Wilson CG. Analgesic effect of oral glucose in neonates. Med J Armed Forces India 2003;59:100-4.

41. Gradin M, Finnstrom O, Schollin J. Feeding and oral glucoseadditive effects on pain reduction in newborns. Early Hum Dev 2004;77:57-65.

42. Ling JM, Quah BS, Van Rostenberghe H. The safety and efficacy of oral dextrose for relieving pain following venepuncture in neonates. Med J Malaysia 2005;60:140-5.

43. Ahn HY, Jang MY, Hur MH. The effect of oral glucose on pain relief in newborns. Taehan Kanho Hakhoe Chi 2006;36:992-1001.

44. Brovedani P, Montico M, Shardlow A, Strajn T, Demarini S. Suckling and sugar for pain reduction in babies. Lancet 2007;369:1429-30.

45. Golestan M, Akhavan Karbasi S, Modares-Mosadegh M, Sadr-Bafghi M. Analgesic effects of glucose and water in neonates. Acta Med Iran 2007;45:461-4.

46. Shadkam MN, Lotfi MH. Pain reducing in icteric newborns while venipuncturing: Comparison of local anesthetic cream with orally glucose. Acta Med Iran 2008;46:59-64.

47. Bonetto G, Salvatico E, Varela N, Cometto C, Gomez PF, Calvo B. Pain prevention in term neonates: Randomized trial for three methods. Arch Argent Pediatr 2008;106:392-6.

48. Skogsdal Y, Eriksson M, Schollin J. Analgesia in newborns given oral glucose. Acta Paediatr 1997;86:217-20.

49. Eriksson M, Gradin M, Schollin J. Oral glucose and venepuncture reduce blood sampling pain in newborns. Early Hum Dev 1999;55:211-8

50. Freire NB, Garcia JB, Lamy ZC. Evaluation of analgesic effect of skin-to-skin contact compared to oral glucose in preterm neonates. Pain 2008;139:28-33.

51. Axelin A, Salantera S, Kirjavainen J, Lehtonen L. Oral glucose and parental holding preferable to opioid in pain management in preterm infants. Clin J Pain 2009;25:138-45.

52. Chermont AG, Falcao LF, de Souza Silva EH, de Cassia Xavier Balda R, Guinsburg R. Skin-to-skin contact and/or oral 25\% dextrose for procedural pain relief for term newborn infants. Pediatrics 2009;124:e1101-7.

53. Olsson E, Eriksson M. Oral glucose for pain relief during eye examinations for retinopathy of prematurity. J Clin Nurs 2011;20:1054-9.
54. Stevens B, Johnston C, Petryshen P, Taddio A. Premature Infant Pain Profile: Development and initial validation. Clin J Pain 1996;12:13-22.

55. Grunau RV, Craig KD. Pain expression in neonates: Facial action and cry. Pain 1987;28:395-410.

56. Carbajal R, Paupe A, Hoenn E, Lenclen R, Olivier-Martin M. APN: A behavioral acute pain rating scale for neonates. Arch Pediatr 1997;4:623-8.

57. Lawrence J, Alcock D, McGrath P, Kay J, MacMurray SB, Dulberg C. The development of a tool to assess neonatal pain. Neonatal Netw 1993;12:59-66.

58. Craig KD, Whitfield MF, Grunau RV, Linton J, Hadjistavropoulos HD. Pain in the preterm neonate: Behavioural and physiological indices. Pain 1993;52:287-99.

59. Bellieni CV, Bagnoli F, Sisto R, Neri L, Cordelli D, Buonocore G. Development and validation of the $\mathrm{ABC}$ pain scale for healthy fullterm babies. Acta Paediatr 2005;94:1432-6.

60. Liu MF, Lin KC, Chou YH, Lee TY. Using non-nutritive sucking and oral glucose solution with neonates to relieve pain: A randomised controlled trial. J Clin Nurs 2010;19:1604-11.

61. Krechel SW, Bildner J. CRIES: A new neonatal postoperative pain measurement score. Initial testing of validity and reliability. Paediatr Anaesth 1995;5:53-61.

62. Taddio A, Nulman I, Koren BS, Stevens B, Koren G. A revised measure of acute pain in infants. J Pain Symptom Manage $1995 ; 10: 456-63$.

63. Kassab MI, Roydhouse JK, Fowler C, Foureur M. The effectiveness of glucose in reducing needle-related procedural pain in infants. J Pediatr Nurs 2012;27:3-17.

64. Johnston CC, Stevens B, Craig KD, Grunau RV. Developmental changes in pain expression in premature, full-term, two- and fourmonth-old infants. Pain 1993;52:201-8.

65. Johnston CC, Stevens BJ. Experience in a neonatal intensive care unit affects pain response. Pediatrics 1996;98:925-30.

66. Harrison D, Stevens B, Bueno M, et al. Efficacy of sweet solutions for analgesia in infants between 1 and 12 months of age: A systematic review. Arch Dis Child 2010;95:406-13.

67. Gradin M. Effect of oral glucose on the heart rate of healthy newborns. Acta Paediatr 2005;94:324-8.

68. Blass EM, Ciaramitaro V. A new look at some old mechanisms in human newborns: Taste and tactile determinants of state, affect, and action. Monogr Soc Res Child Dev 1994;59:I-V,1-81.

69. Gibbins S, Stevens B. Mechanisms of sucrose and non-nutritive sucking in procedural pain management in infants. Pain Res Manag 2001;6:21-8.

70. Stevens B, McGrath P, Gibbins S, et al. Procedural pain in newborns at risk for neurologic impairment. Pain 2003;105:27-35.

71. Carbajal R, Rousset A, Danan C, et al. Epidemiology and treatment of painful procedures in neonates in intensive care units. JAMA 2008;300:60-70. 


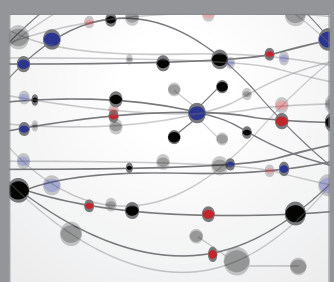

The Scientific World Journal
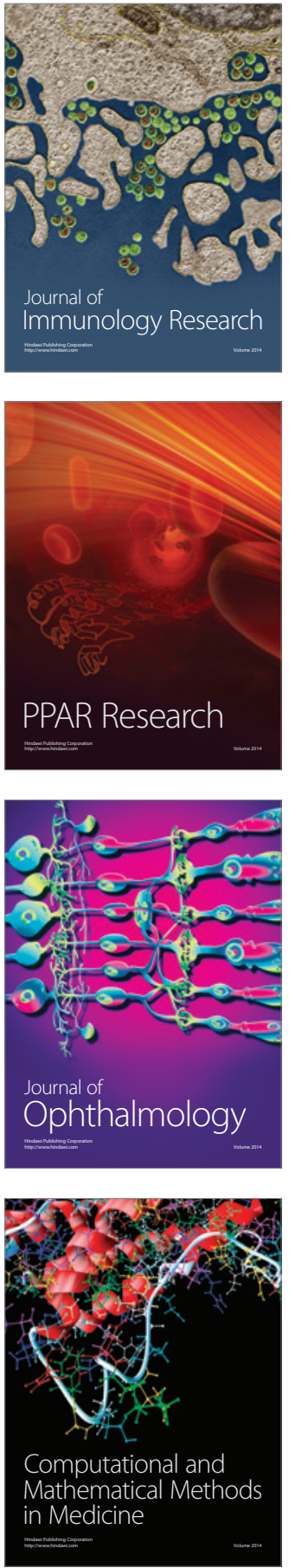

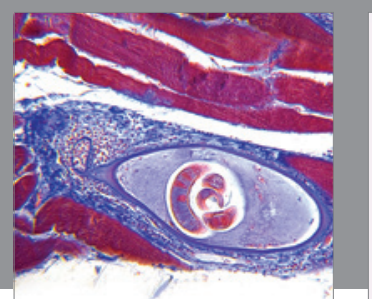

Gastroenterology Research and Practice

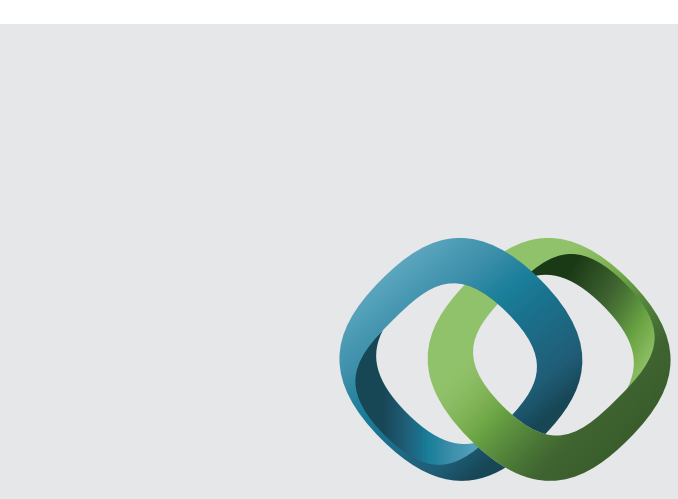

\section{Hindawi}

Submit your manuscripts at

http://www.hindawi.com
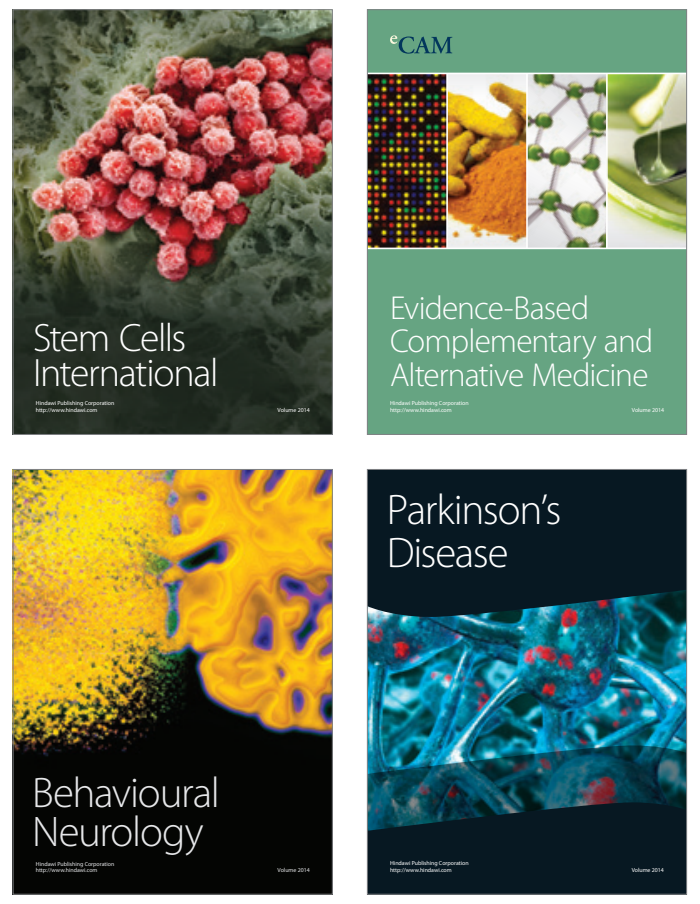
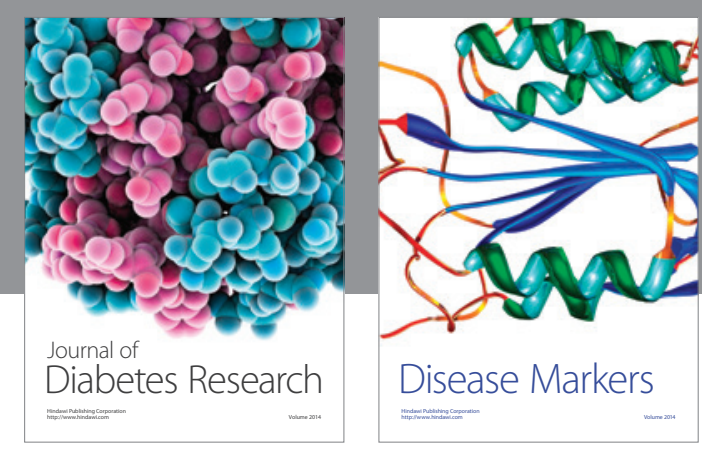

Disease Markers
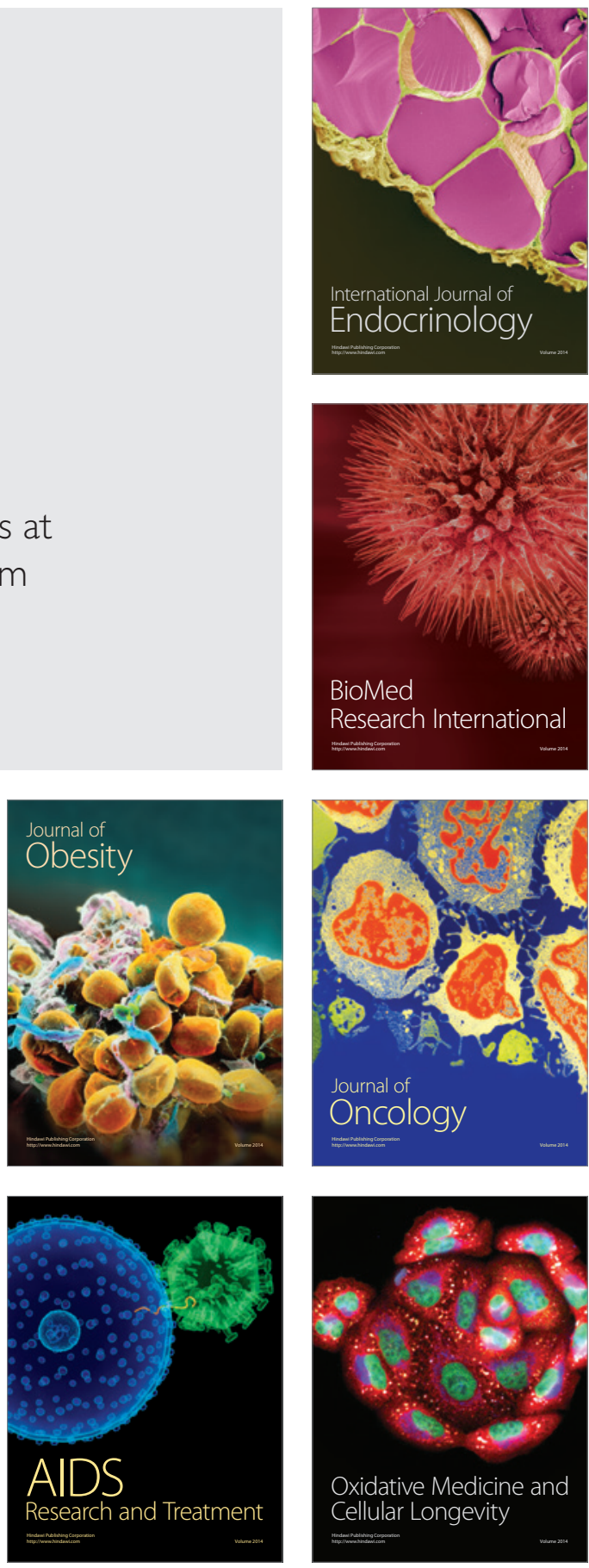